\title{
TEMUAN BELIUNG DI KAWASAN DANAU: Studi Kasus di Kawasan Beberapa Ranu di Jawa Timur
}

\author{
STONE ADZES FROM LAKE REGION: \\ Case Study in Some Lakes Region in East Java Province
}

\author{
Gunadi Kasnowihardjo \\ Balai Arkeologi Yogyakarta \\ gunbalar@yahoo.com
}

\begin{abstract}
The stone adze, both rectangular adze or pick adze, is one of the Neolithic tools's characteristics. In the Asia-Pacific region, stone adze is contemporaneous with the spreading of Austronesian speakers. In East Java province two types of stone tools were found in the lakes region, that assumed as a past settlement. Stone adzes found in the lakes region sites are new data that can complement the data related to the distribution of stone adze in Java, particularly in East Java. Is it true that the findings of the stone adze has a connection with the humans that inhabitants the lake area? Based of these research questions, this research need to be conducted. To answer the research question, spatial archaeological approach issued and also a petrographic analysis of several stone adze samples and stone adze's rocks material from these research need to be conducted.
\end{abstract}

Keywords: Stone adze, Neolithic, Austronesian, New data, Lakes area, East Java.

\begin{abstract}
ABSTRAK
Alat batu Beliung baik rectangular adze maupun pick adze merupakan salah satu ciri perkakas masa Neolitik. Di kawasan Asia-Pasifik, jenis perkakas ini dikenal sejaman dengan sebaran bangsa-bangsa penutur rumpun bahasa Austronesia. Di Provinsi Jawa Timur kedua jenis perkakas batu tersebut ditemukan di kawasan danau-danau yang diperkirakan sebagai kawasan permukiman masa lampau. Temuan beliung di situs-situs di kawasan danau merupakan data baru yang dapat melengkapi data tentang sebaran beliung di Jawa, khususnya di Jawa Timur. Benarkah temuan Beliung tersebut memiliki hubungan dengan manusia penghuni kawasan danau? Atas dasar pertanyaan tersebut, maka penelitian ini dilakukan. Untuk menjawab pertanyaan penelitian itu digunakan pendekatan arkeologi keruangan dan juga dilakukan analisis petrografi dari beberapa sampel Beliung dan batuan dari hasil penelitian ini.
\end{abstract}

Kata kunci : Beliung, Neolitik, Austronesia, Data baru, Kawasan danau, Jawa Timur.

Tanggal masuk : 2 September 2014

Tanggal diterima : 3 November 2014 


\section{PENDAHULUAN}

Penelitian Permukiman Masa Lampau di Kawasan Danau di wilayah 栾@ Provinsi Jawa Timur adalah tema penelitian penulis yang sekaligus merupakan salah satu kegiatan dari Rencana Strategis Penelitian Balai Arkeologi Yogyakarta tahun 2009 2014. Selama 5 (lima) tahun ini penelitian dilakukan di wilayah Kabupaten Lumajang, Probolinggo, dan Pasuruan yang mencakup beberapa kawasan danau yaitu Ranu Klakah, Ranu Gedang, Ranu Segaran, Ranu Bethok, dan Ranu Grati. Kata ranu adalah sebutan masyarakat setempat untuk sebuah danau. Penelitian ini dilatari berbagai pertanyaan penelitian terutama tentang permasalahan sebaran budaya bangsa Austronesia di Jawa, khususnya di daerah Jawa Timur. Bangsa penutur rumpun bahasa Austronesia yang diyakini sebagai nenek moyang bangsa Indonesia hingga saat ini masih menyisakan misteri. Hal ini seperti ditulis dalam pengantar buku berjudul: "Polemik tentang Masyarakat Austronesia Fakta atau Fiksi?" (2004, vii), bahwa penelitian tentang Austronesia telah berlangsung kurang lebih dua abad, namun hingga kini masih banyak sisi gelap yang belum terungkap.

Bangsa penutur rumpun bahasa Austronesia identik dengan bangsa pendukung budaya Neolitik yang berasal dari daratan China Selatan. Mereka selain telah mengenal teknologi pembuatan perahu bercadik, juga telah mengenal cara bercocok tanam padi, jewawut, tebu, ubi, dan keladi, serta telah memiliki pengetahuan dan teknologi pembuatan tembikar, tenun, kulit kayu, dan benda-benda baik yang terbuat dari tulang maupun batu, seperti misalnya pisau, mata panah, dan beliung (Bellwood, 2000: 352). Kemampuan ilmu pengetahuan dan teknologi itulah yang akhirnya mampu merubah cara hidup manusia dari food gathering ke food producing saat itu, yang oleh V. Gordon Childe disebut dengan istilah Revolusi Neolitik, baik yang terjadi di Eropa maupun di China
(Childe 1965, 66-70). Selama beberapa millennium perjalanan bangsa Austronesia dari Taiwan hingga mencapai Pasifik di Timur, New Zealand di Selatan dan Madagaskar di barat, mereka mempertahankan dan mengembangkan ilmu pengetahuan dan teknologinya, sehingga secara artefaktual sisa-sisanya dapat ditemukan di titik-titik sepanjang perjalanan mereka. Salah satu jenis artefak hasil dari teknologi mereka adalah beliung batu atau rectangular adze (Heekeren 1972, 160-161).

Di Indonesia umumnya dan di Jawa khususnya, informasi tentang sebaran beliung sejak tahun 1972 oleh H. R. Van Heekeren hingga sekarang belum ada ahli yang memetakan kembali dan memperbarui peta sebaran Beliung tersebut. Situs-situs di kawasan ranu seperti tersebut di atas dalam buku The Stone Age of Indonesia tidak disebutkan sebagai situs-situs tempat ditemukannya Beliung. Oleh karena itu, selain akan memberikan penjelesan tentang temuan Beliung dan kehidupan masyarakat masa lampau di kawasan ranu, artikel ini diharapkan dapat menambah informasi sebaran Beliung yang terkait pula dengan perjalanan bangsa penutur bahasa Austronesia di Jawa, khususnya di wilayah Provinsi Jawa Timur.

\section{POLA PERMUKIMAN DI KAWASAN RANU}

Temuan yang bersifat artefaktual seperti misalnya lumpang batu, fragmen tembikar dan keramik baik hasil dari ekskavasi maupun survey permukaan, serta data artefaktual lainnya seperti beliung, belincung dan bakal calon beliung yang ditemukan oleh masyarakat setempat atau merupakan benda warisan yang ditinggalkan secara turun-temurun. Sedangkan data yang bersifat non artefaktual antara lain lansekap budaya (cultural landscape), sumber air, kesuburan tanah dan keberadaan danau atau ranu itu sendiri semuanya menunjukkan adanya indikasi permukiman masa lampau di kawasan danau. 
Artefak yang dicurigai memiliki umur tertua di antara artefak lainnya adalah beliung dan belincung yang oleh masyarakat lokal disebut dengan istilah gege kelap (Bahasa Madura, yang artinya gigi petir). Istilah gigi petir rupanya diyakini secara universal oleh berbagai etnis baik di Indonesia maupun di wilayah Asia Tenggara (Heekeren 1972, 156-157). Contoh sampel Beliung dan Belincung dari masing-masing kawasan danau akan dijelaskan di bawah. Indikator permukiman masa lampau berikutnya adalah sumberdaya alam dan lingkungan yang merupakan bagian dari ekosistem dalam kehidupan manusia, yaitu sumber air. Sampai saat ini kebutuhan air masyarakat penghuni kawasan danau-danau di Jawa Timur masih tergantung dari sumber air, kecuali masyarakat di kawasan danau Ranu Grati yang sudah banyak membuat sumur.

$$
\text { Dengan }
$$

menggunakan

pendekatan arkeologi keruangan, hasil penelitian di kawasan danau atau ranu baik ranu yang memiliki debit air melimpah seperti Ranu Klakah maupun ranu yang debit airnya telah menyusut seperti Ranu Gedhang dan Ranu Bethok, secara garis besar dapat disimpulkan bahwa : Pola permukiman masa lampau di kawasan danau berada pada lahan yang relative datar dan subur, tidak jauh dari danau dan sumber air, Pola permukiman masa lampau di kawasan danau ditandai pula oleh keberadaan kubur cikal-bakal yang menunjukkan sebagai makam tertua penghuni kawasan tersebut. Rupanya pola permukiman masa lampau di kawasan danau ini berpola acak mengikuti kondisi topografi, lansekap dan potensi sumberdaya alam yang ada. Hal ini berbeda dengan pola permukiman di kawasan danau di Eropa pada umumnya yang secara linear mengelilingi tepian danau, bahkan adapula permukiman dengan rumahrumah yang dibangun di atas perairan danau seperti yang ditemukan di Swiss, Austria, Perancis, dan Switzerland (Menotti 2004, 179-190).

\section{BELIUNG DI KAWASAN RANU}

Van Heekeren (1972) menjelaskan bahwa di Jawa Timur sebaran beliung ditemukan di Madiun, Surabaya, Madura, Malang, dan yang paling banyak di Besuki. Dari Kendeng Lembu dan Pager Gunung, keduanya di kawasan Glenmore, Banyuwangi, Heekeren selama dua tahun membeli lebih dari dua ribu buah beliung diupam (beliung yang sudah diasah sehingga permukaannya halus). Berdasarkan temuan beberapa buah bakal calon beliung dan sebaran serpih hasil pemangkasan calon beliung tersebut, lebih lanjut dijelaskan bahwa daerah Kendeng Lembu dan Pager Gunung merupakan situs perbengkelan dan situs permukiman (Heekeren 1972, 168-169). Berdasarkan pola permukiman seperti diuraikan sebelumnya dapat dijelaskan bahwa di kawasan danau-danau di Jawa Timur belum ditemukan situs perbengkelan beliung dan alat batu lainnya. Temuan bakal calon beliung di Situs Ranu Klakah belum dapat menjelaskan tentang adanya situs perbengkelan yang dimaksud (Nitihaminoto 2007; 2008). Di bawah akan diuraikan beliung dan belincung temuan di kawasan ranu-ranu seperti berikut:

\section{Temuan Beliung dan Belincung di Kawasan Ranu}

Temuan hasil survey seperti beliung, fragmen tembikar dan benda terakota yang diperkirakan sebagai bandul jala, secara artefaktual menunjukkan tanda-tanda kehidupan manusia dari masa lampau di kawasan danau. Keberadaan makam tua, punden, dan sumur kuna, semua itu menunjukkan tentang okupasi manusia di kawasan tersebut. Beberapa beliung dan belincung dan bakal calon beliung ditemukan oleh survei tim penelitian di 5 (lima) kawasan ranu. Semua temuan beliung dan belincung serta bakal calon beliung tersebut adalah temuan sekunder, karena bukan temuan langsung oleh tim survei akan tetapi temuan lama oleh penduduk setempat 
atau merupakan benda warisan dari orang tua mereka. Beberapa contoh beliung, belincung, dan bakal calon beliung temuan di kawasan danau迹@ danau di Jawa Timur antara lain sebagai berikut:

\section{Belincung Ranu Klakah}

Belincung ini dibuat dari material batu pasir silikaan (silicified sand stone) dan saat ditemukan dalam keaadaan patah pada bagian pangkal. Fragmen belincung ini berukuran panjang 20.8 $\mathrm{Cm}$, lebar $6.0 \mathrm{Cm}$, dan tebal $0.7 \mathrm{Cm}$. Pada bagian tajaman terdapat luka bekas pakai sebagai bukti atau tanda bahwa belincung tersebut merupakan peralatan yang digunakan untuk keperluan rumah tangga. Belincung ini ditemukan oleh penduduk pada tahun 1970-an.

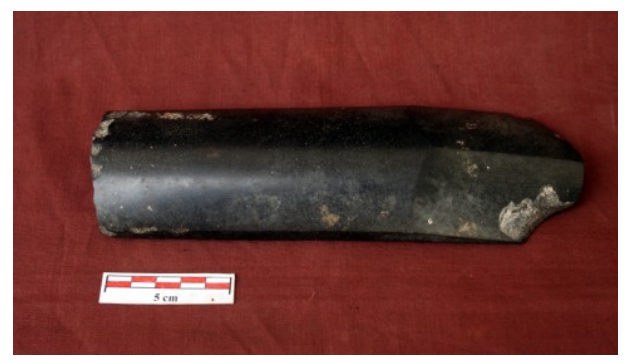

Gambar 1. Belincung Ranu Klakah (Sumber: Nitihaminoto 2007)

\section{Bakal Calon Beliung Ranu Klakah}

Temuan bakal calon beliung ini satu-satunya temuan plank yang ditemukan di kawasan danau. Calon alat batu ini ditemukan di kawasan danau Ranu Klakah oleh salah seorang warga Dusun Krajan, Desa Tegal Randu, Kecamatan Klakah, Kabupaten Lumajang, Jawa Timur. Bakal calon beliung ini berukuran panjang $16.5 \mathrm{Cm}$, lebar $4.5 \mathrm{Cm}$, dan tebal $3.5 \mathrm{Cm}$. Seperti halnya belincung Ranu Klakah, calon beliung ini juga dibuat dari bahan batu pasir silikaan. Oleh karena temuan yang baru satu-satunya, serta belum ditemukan sisa-sisa serpihan hasil pemangkasan dari pembuatan alat batu, maka secara kontekstual tidak ada kaitannya dengan situs perbengkelan.

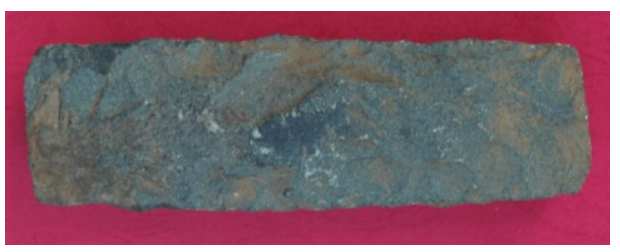

Gambar 2. Bakal Calon Beliung/Belincung Ranu Klakah

(Sumber: Nitihaminoto 2007)

\section{Beliung Ranu Gedhang}

Penelitian di kawasan danau Ranu Gedhang mendapatkan informasi tentang temuan 2 (dua) buah beliung oleh penduduk Blok Ledhuk, Dusun Ranu Gedang Timur, Desa Ranu Gedang, Kecamatan Tiris, Kabupaten Probolinggo, Jawa Timur. Semula, kedua temuan beliung tersebut oleh pemiliknya dirahasiakan, karena dipercaya sebagai benda keramat. Berdasarkan informasi dari pemilik yaitu Bapak Edi Sugianto, kedua beliung ditemukan di bawah rumpun bambu di depan rumahnya oleh seorang anak saat bermain di sekitar lokasi tersebut. Sampai saat ini pemilik kedua beliung itu masih merawatnya dan tidak sembarang orang dapat melihatnya. Pada saat anggota tim penelitian Situs Ranu Gedhang mendapatkan kesempatan mengambil gambar kedua beliung tersebut, maka pemotretan dilakukan dengan terburu-buru sehingga tidak sempat melakukan pengukuran kedua alat batu tersebut.

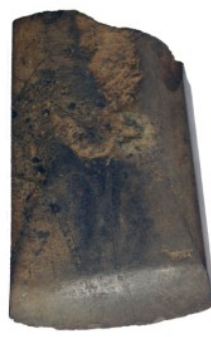

1

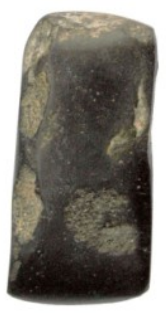

2
Gambar 3. Beliung Ranu Gedhang (Sumber : Gunadi, dkk. 2008)

\section{Beliung Ranu Segaran}

Seperti di kawasan Ranu Gedhang, di kawasan Ranu Segaran juga ditemukan beliung yang secara morfologis mempunyai ciri-ciri yang sama dengan beliung dari kawasan danau di Jawa Timur lainnya yaitu: 
tajaman berbentuk cembung, lereng tajaman landai, bagian lateral kiri dan kanan lurus, proksimal datar, sedangkan bidang atas dan bidang bawah relatif cembung, serta telah diupam.

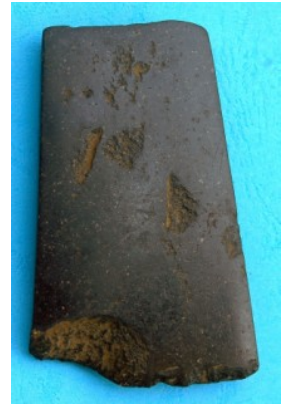

1

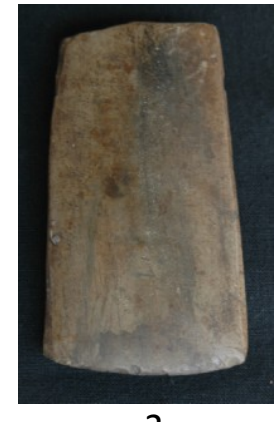

2
Gambar 5. Dua beliung dari Ranu Segaran (Sumber: Gunadi dkk, 2009).

\section{Beliung dan Belincung Ranu Bethok}

Temuan alat batu di kawasan Ranu Bethok antara lain beberapa buah beliung dan sebuah fragmen belincung (yang pada bagian belakang telah patah dan hilang). Fragmen belincung ini memiliki ukuran panjang $12 \mathrm{Cm}$, lebar $5.5 \mathrm{Cm}$, dan tebal $3 \mathrm{Cm}$. Apabila dibandingkan dengan temuan belincung dari Ranu Klakah atau Ranu Grati rupanya belincung Ranu Bethok berukuran yang sama dengan kedua belincung tersebut.

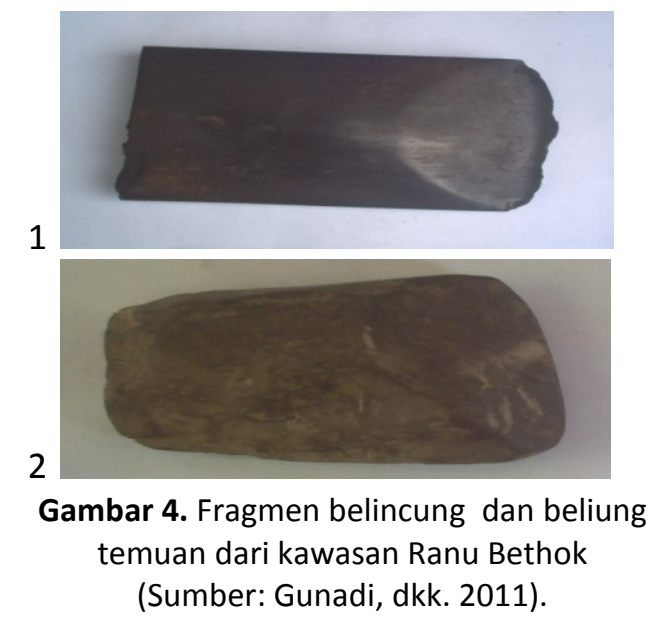

Temuan beliung di kawasan danau Ranu Bethok agak berbeda dengan beliung Ranu Gedhang maupun Ranu Segaran. Hasil analisis beliung temuan Bapak Moris warga Dusun Ranu Bethok, Desa Ranu Agung, Kecamatan Tiris, Kabupaten Probolinggo, Jawa
Timur ini tidak ditemukan tanda-tanda pemakaian. Selain itu, bahan batuan yang digunakan adalah batuan gamping yang memiliki kekerasan rendah, serta tidak ditemukan bekas pemakaian.

\section{Beliung dan Belincung Ranu Grati}

Berdasarkan informasi dari masyarakat, beliung dan belincung temuan dari kawasan danau Ranu Grati merupakan temuan sekunder, yaitu temuan masyarakat baik saat menggali pasir maupun saat melakukan kegiatan lain di lahan tegalan yang terletak di kawasan danau Ranu Grati. Baik beliung maupun belincung temuan di kawasan danau Ranu Grati pada bagian tajamannya ditemukan tanda-tanda bekas pemakaian, kecuali beliung temuan Bapak Ahmad warga Dusun Krikilan, Desa Kalipang, Kecamatan Grati yang bentuk dan bahannya berbeda dengan beliung pada umumnya. Beliung temuan Pak Ahmad yaitu terbuat dari bahan batuan gamping yang memiliki kekerasan rendah, sehingga kurang baik apabila digunakan sebagai alat. Rupanya bagi masyarakat penghuni kawasan danau di Jawa Timur beliung tidak hanya difungsikan sebagai alat rumah tangga untuk keperluan sehari-hari, akan tetapi adapula yang difungsikan sebagai benda regalia yang diyakini memiliki kekuatan supranatural. Kemungkinan lain, benda yang diyakini oleh penemunya sebagai gigi petir ini kemungkinan telah mengalami deformasi akibat pemakaian sebagai batu asah oleh pemilik sebelumnya. Seperti diceritakan oleh beberapa warga masyarakat penghuni kawasan danau di Jawa Timur, hingga tahun 1970 an masih banyak para warga yang menggunakan gigi petir (beliung atau fragmen beliung) sebagai batu asah untuk mengasah dan mempertajam sabit saat mereka mencari rumput untuk pakan ternak. Seperti diceritakan oleh Bapak Sudarmin salah seorang penemu beliung warga Blok Bethok, Desa Ranu Agung, Kecamatan Tiris bahwa sebagian besar para pencari rumput pada waktu dulu saat mereka mencari rumput selalu membawa beliung atau 
fragmen beliung. Benda ini sangat praktis karena mudah dibawa dan setiap saat sabit mulai tumpul langsung dapat dilakukan pengasahan tanpa harus () pergi mencari batu asah.

(1)
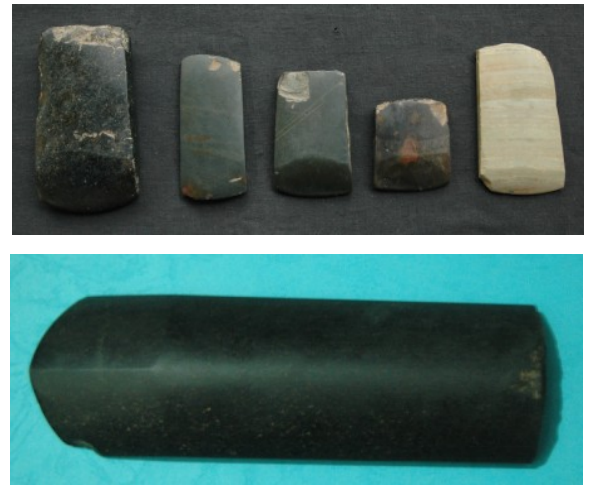

Gambar 6. Beliung dan belincung temuan di kawasan danau Ranu Grati, Pasuruan (Sumber: Gunadi, dkk. 2012).

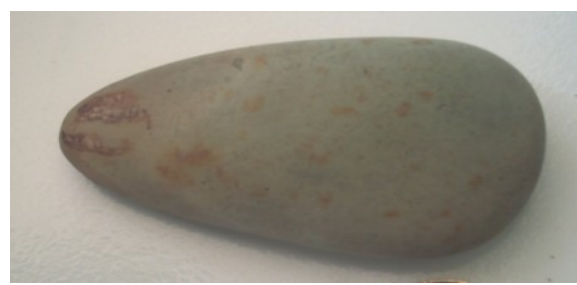

Gambar 7. Beliung Temuan Pak Ahmad (Sumber: Gunadi dkk. 2012)

\section{Beliung dan Masyarakat Ranu}

Pada umumnya masyarakat di wilayah Lumajang, Probolinggo dan Pasuruan menyebut beliung baik yang berukuran besar maupun kecil dengan istilah gege kelap (gigi petir). Secara universal istilah gigi petir digunakan oleh etnis-etnis yang tersebar di Indonesia. Masyarakat Aceh menyebutnya ipon pungi (lintasgayo.co/2013/06/21wargatakengon-temukan-ipon-pungi), dan di Jawa orang menyebut Beliung dengan untu bledek. Sedangkan gege kelap adalah sebutan yang diberikan oleh masyarakat etnis Madura yang mendiami ketiga wilayah di atas atau yang dikenal sebagai "Kawasan Tapal Kuda".

Sebagian besar beliung di kawasan ranu ditemukan oleh masyarakat beberapa saat setelah hujan reda, adapula yang ditemukan di sekitar pohon yang tersambar petir. Lokasi temuan pada umumnya di areal yang saat ini merupakan lahan tegalan. Ada atau tidak sesuatu yang tersambar petir di lokasi temuan beliung, masyarakat selalu mengkaitkan keberadaan beliung tersebut dengan petir yang muncul saat hujan. Pada masyarakat yang sekarang ini bermukim di kawasan ranu, baik secara teknis maupun filosofis mereka tidak tahu latar sejarah tentang keberadaan beliung tersebut. Pemahaman masyarakat tentang beliung yang diidentifikasikan sebagai gigi petir oleh masyarakat di sekitar ranu merupakan sesuatu yang universal. Berbeda dengan masyarakat lain, penduduk di kawasan Ranu Grati mengenal mitos gigi petir beserta simbol personifikasinya. Seperti diceritakan oleh H. Usman (70 Thn) warga Dusun Krikilan, Desa Gratitunon, Kecamatan Grati, Kabupaten Pasuruan, masyarakat sekitar Ranu Grati mengenal dua jenis petir yaitu, Kelap Pecok yaitu jenis petir yang apabila mengenai sebuah pohon, maka pohon tersebut akan patah batangnya atau batang tersebut terbelah dua. Kedua adalah Kelap Air yaitu apabila sebuah pohon tersambar petir jenis ini, maka daun-daunnya seperti tersiram air yang berakibat kering dan akhirnya rontok.

Beliung yang sekarang disimpan oleh masyarakat di sekitar ranu sebagian diperoleh secara turuntemurun, dan adapula yang ditemukan langsung oleh si pemilik (Gunadi, dkk. 2010-2013). Hal seperti ini sering terjadi di tempat lain di Asia Tenggara, masyarakat menemukan beliung batu dari dalam tanah saat mereka mencangkul lahan pertanian mereka, atau menemukan di bawah pohonpohon besar yang tumbang karena tersambar petir. Sebagian besar beliung dan belincung tidak ditemukan dari kegiatan penggalian secara ilmiah (Koentjaraningrat 1982, 13). Sebagian besar masyarakat ranu masih percaya akan adanya tuah yang melekat pada beliung sehingga mereka mengkeramatkannya hingga sekarang. Seperti yang diyakini oleh kaum wanita 
di sekitar Ranu Bethok, apabila beliung batu ditaruh di dalam genuk (tempat beras), maka beras yang ada di dalam genuk tersebut tidak akan cepat habis dan diyakini akan mencukupi untuk keperluan keluarga, hingga tiba masa panen berikutnya. Namun demikian, adapula yang menggunakan beliung untuk mengasah sabit. Benda yang berukuran kecil itu sangat praktis untuk mengasah sabit karena mudah dibawa saat orang mencari rumput (Gunadi, dkk. 2010).

\section{Beliung dan Belincung Ranu dalam Perbandingan}

Colin Renfrew dan Paul Bahn dalam The Cambridge World Prehistory: Africa, South and Southeast Asia and the Pacific (2014) menyebutkan bahwa beliung seperti yang ditemui di situs perbengkelan Punung dekat Pacitan adalah elemen penting yang dibawa bersama budaya Austronesia. Selain situs perbengkelan Punung, sejumlah beliung juga ditemukan di kawasan danau-danau di Jawa Timur yang diidentifikasi sebagai artefak dari masa prasejarah, mengingatkan kita akan adanya bengkel Beliung di wilayah Kendenglembu, Kabupaten Banyuwangi, Jawa Timur dan juga situs perbengkelan Beliung di wilayah Kabupaten Purbalingga, Jawa Tengah (Heekeren, 1972; Anonim, 1979; Simanjuntak, 1984; Soejono dan Leirissa, 1992; dan Noerwidi, 2008). Sofwan Noerwidi yang saat ini tengah melakukan analisis beberapa beliung dari Punung, Pacitan dan Patiayam, Kudus menyatakan bahwa beliung Punung sebagian besar dibuat dari batuan Rijang dan adapula Kalsedon. Sedangkan beliung Situs Kendenglembu rata-rata terbuat dari batuan Rijang hijau dan adapula yang terbuat dari batuan pasir tersilika (silicified sand stone). Adapun beliung dari Situs di wilayah Purbalingga, Jawa Tengah kebanyakan terbuat dari batuan Rijang hijau (wawancara pribadi dengan Sdr. Sofwan Noerwidi pada tanggal 12 Januari 2015 di Balai Arkeologi Yogyakarta). Dari penelitian tentang beliung sejak Van Stein Callenfels (1929) hingga sekarang dapat disimpulkan bahwa pengerjaan pembuatan Beliung diawali dengan pemangkasan, penyerpihan, penggosokan, dan pengupaman. Beliung yang ditemukan di kawasan ranu - ranu di Jawa Timur terdiri dari dua jenis. Jenis yang pertama berbentuk memanjang dengan penampang lintang persegi.Tajaman dibuat dengan mengasah bagian ujung permukaan melandai kearah ujung, hingga diperoleh bentuk tajaman yang miring, mirip tajaman pahat buatan masa kini (Soejono dan Leirissa 1992, 206-210). Jenis kedua yaitu beliung punggung tinggi sehingga memiliki penampang lintang berbentuk segitiga, segilima, atau setengah lingkaran (tapal kuda). Beliung ini sering disebut pula dengan istilah belincung yang fungsinya untuk memotong kayu atau mencangkul tanah.

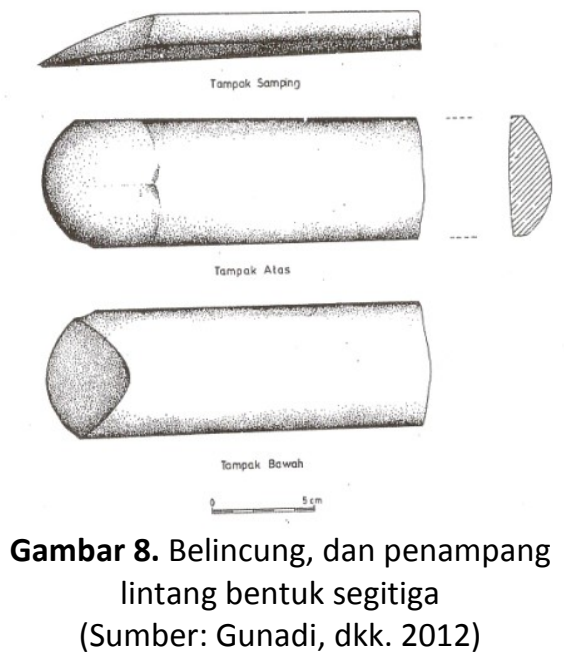




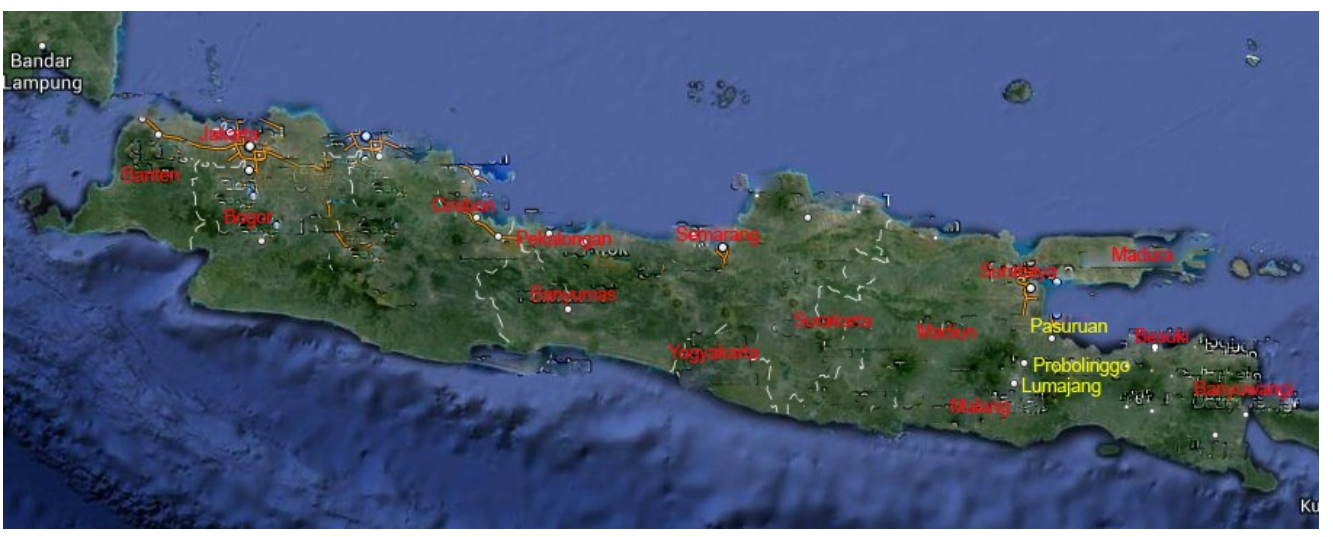

Gambar 9. Peta Sebaran Beliung di Jawa

(Sumber: Heekeren 1972 dan Gunadi 2009-2013)

Selain gerabah, beliung dan belincung merupakan salah satu ciri peralatan rumah tangga yang dikenal oleh manusia penutur rumpun bahasa Austronesia yang dikenal pada masa Neolitik. Beliung dan belincung baik yang ditemukan di Indonesia ataupun Negara-negara Asia Tenggara lainnya memiliki bentuk dan ukuran yang hampir sama, sedangkan bahan baku tergantung dari sumber bahan yang tersedia. Material atau bahan baku untuk pembuatan beliung biasanya berups batuan jaspis, rijang, agat, gamping kersikan, basal, andesit, sabak, batu pasir, atau kalsedon (Anonim 1997, 26). Untuk bahan beliung temuan dari hasil penelitian di kawasan danau di Jawa Timur rata-rata dari batuan basal dan rijang, sedangkan untuk belincung digunakan batuan jaspis atau kalsedon (pengamatan di lapangan oleh tim survei geologi). Peta sebaran temuan beliung $\mathrm{di}$ atas menunjukkan adanya data baru temuan beliung dari wilayah Kabupaten Lumajang, Probolinggo, dan Pasuruan. Selain itu, juga tambahan data tentang adanya relung-relung permukiman masa lampau di kawasan danau di wilayah Provinsi Jawa Timur, sehingga dapat melengkapi informasi tentang sebaran beliung khususnya dan data prasejarah di Jawa Timur pada umumnya.

Beberapa sampel beliung yang berhasil dianalisis secara petrografis dapat dibandingkan dengan hasil analisis petrografis batuan lokal ataupun bahan beliung dari situs lain yaitu Situs Tipar-Ponjen di Kabupaten Purbalingga, Jawa Tengah. Adapun hasil analisis petrografi beberapa sampel tersebut adalah sbb.:

Tabel 1. Unsur dan kandungan mineral batuan pada Beliung dan material batuan lokal

\begin{tabular}{|c|l|l|c|l|}
\hline No. & JENIS SAMPEL & UNSUR MINERAL & $(\%)$ & \multicolumn{1}{|c|}{ KETERANGAN } \\
\hline 1. & Beliung Ranu Bethok-1 & Glass & 40 & Nama Batuan : Kristal \\
& & Mineral Opak & 35 & Tuf, (berdasarkan \\
& & Plagioklas & 10 & klasifikasi \\
& & Quatrz & 10 & (Petrijohn, 1975) \\
\hline 2. & Beliung Ranu Bethok-2 & Glass & 5 & \\
& & Mineral Opak & 80 & Nama Batuan : Vitric Tuf, \\
& & Plagioklas & 5 & (berdasarkan klasifikasi \\
& & Quatrz & 5 & \\
\hline 3. & \multirow{2}{*}{ Beliung Ranu Segaran-1 } & Glass & 40 & Nama Batuan : Vitric Tuf, \\
& & Mineral Opak & 40 & (berdasarkan klasifikasi \\
& & Plagioklas & 10 & (Petrijohn, 1975) \\
& & Quatrz & 5 & \\
& & Lithic & 5 & \\
\hline
\end{tabular}




\begin{tabular}{|c|c|c|c|c|}
\hline 4. & Beliung Ranu Segaran-2 & $\begin{array}{l}\text { Chlorit } \\
\text { Mud } \\
\text { Mineral Opak } \\
\text { Plagioklas } \\
\text { Quatrz } \\
\text { Lithic } \\
\end{array}$ & $\begin{array}{c}20 \\
10 \\
10 \\
40 \\
5 \\
5\end{array}$ & $\begin{array}{l}\text { Nama Batuan: } \\
\text { Chiefly Volcanic Wacke } \\
\text { (Klasifikasi Gilbert, 1954). }\end{array}$ \\
\hline 5. & $\begin{array}{l}\text { Batuan Lokal } \\
\text { Kawasan Ranu Bethok }\end{array}$ & $\begin{array}{l}\text { Plagioklas } \\
\text { Mineral Opak } \\
\text { Massa Gelas } \\
\text { Sanidin } \\
\text { Quartz } \\
\text { Hornblende }\end{array}$ & $\begin{array}{c}50 \\
20 \\
15 \\
5 \\
3 \\
2\end{array}$ & $\begin{array}{l}\text { Nama Batuan: Andesit } \\
\text { (Klasifikasi Williams, } \\
\text { 1982). }\end{array}$ \\
\hline 6. & Beliung Solikhin-Grati & $\begin{array}{l}\text { Plagioklas } \\
\text { Piroksen } \\
\text { Mineal Opak } \\
\text { Gelas }\end{array}$ & $\begin{array}{c}65 \\
15 \\
5 \\
15 \\
\end{array}$ & $\begin{array}{l}\text { Nama Batuan: } \\
\text { Piroksen Andesit } \\
\text { (Klasifikasi Williams, } \\
\text { 1982). }\end{array}$ \\
\hline 7. & Beliung Suwarna-Grati & $\begin{array}{l}\text { Kalsit } \\
\text { Kuarsa } \\
\text { Mineral Opak }\end{array}$ & $\begin{array}{c}80 \\
15 \\
5 \\
\end{array}$ & $\begin{array}{l}\text { Nama Batuan: } \\
\text { Calcite Marble (Klasifikasi } \\
\text { Turner, 1982). }\end{array}$ \\
\hline 8. & $\begin{array}{l}\text { Batuan Lokal Kawasan } \\
\text { Ranu Grati-1 }\end{array}$ & $\begin{array}{l}\text { Mineral Lempung } \\
\text { Kuarsa } \\
\text { Mineral Oksida Besi } \\
\text { Mika }\end{array}$ & $\begin{array}{c}70 \\
20 \\
5 \\
5 \\
\end{array}$ & $\begin{array}{l}\text { Nama Batuan : } \\
\text { Meta Claystone } \\
\text { (Klasifikasi Gilbert, 1982). }\end{array}$ \\
\hline 9. & $\begin{array}{l}\text { Batuan Lokal Kawasan } \\
\text { Ranu Grati-2 } \\
\text { (Rijang Coklat) }\end{array}$ & $\begin{array}{l}\text { Mikro Kuarsa } \\
\text { Mineral Oksida Besi }\end{array}$ & $\begin{array}{c}98 \\
2\end{array}$ & $\begin{array}{l}\text { Nama Batuan : Chert } \\
\text { (Klasifikasi Gilbert, 1982). }\end{array}$ \\
\hline 10. & $\begin{array}{l}\text { Batuan Lokal Kawasan } \\
\text { Ranu Grati-3 } \\
\text { (Rijang Merah) }\end{array}$ & $\begin{array}{l}\text { Mikro Kuarsa } \\
\text { Mineral Oksida Besi }\end{array}$ & $\begin{array}{c}93 \\
7\end{array}$ & $\begin{array}{l}\text { Nama Batuan : Chert } \\
\text { (Klasifikasi Gilbert, 1982). }\end{array}$ \\
\hline
\end{tabular}

(Sumber: Laporan Penelitian Permukiman Masa Lampau di Kawasan Danau 2011-2013)

Kepandaian membuat beliung dan belincung bersamaan dengan mulainya domestikasi tanaman seperti keladi dan umbi-umbian serta binatang piaraan seperti ayam, babi dan anjing. Mereka juga telah mengenal teknologi pembuatan perahu bercadik yang mampu mengarungi laut bebas, sehingga mereka sejak saat itu mulai bermigrasi dari pulau satu ke pulau lainnya dalam rangka mencari lahan untuk kehidupan. beliung dan belincung yang ditemukan di kawasan danaudanau di Jawa Timur kemungkinan tidak dibawa dari tanah asal mereka. IImu pengetahuan dan teknologi yang telah mereka kuasai dipraktekkan di wilayahwilayah yang mereka diami, sehingga bahan untuk membuat beliung dan belincung harus ditemukan dari lingkungan alam setempat.

\section{PEMBAHASAN}

Sejak tahun 1800 - 1850 alat batu Neolitik seperti beliung mulai dikoleksi di
Museum Royal Batavia Society, walaupun jauh sebelum itu kira-kira tahun 1705 G. E. Rumphius telah memperkenalkan tentang alat batu tersebut yang diyakini oleh masyarakat Indonesia sebagai gigi petir (Heekeren 1972, 159). Di daerah Aceh alat beliung disebut ipon-pungi yang artinya gigi petir. Seperti Beliung yang ditemukan oleh warga Takengon tahun 2013 yang lalu setelah diamati oleh Ketut Wiradnyana arkeolog dari Balai Arkeologi Medan dipastikan bahwa iponpungi adalah beliung batu dan pernah digunakan sebagai alat (lintasgayo.co/2013/06/21wargatakengon-temukan-ipon-pungi), sedang di kawasan danau-danau di Jawa Timur, Beliung ataupun Belincung disebut gege-kelap yang artinya juga gigi petir. Pengertian dan pemahaman tentang gigi petir rupa-rupanya merupakan kepercayaan yang bersifat universal, sehingga Beliung dan Belincung hasil temuan penelitian di kawasan danaudanau di Jawa Timur dapat dipastikan 
salah satu tinggalan dari budaya Neolitik di kawasan tersebut.

Berdasarkan hasil analisis carbon dating (C14) sampel arang yang diambil (1) dari hasil ekskavasi test pit (TP-2) Situs Ranu Grati diperoleh pertanggalan 660 \pm 110 BP (1950) atau kira - kira tahun 1290 an, atau masa awal kekuasaan Majapahit (Siregar 2014). Pada abad 13 hingga 14 di wilayah Lumajang, Probolinggo, dan Pasuruan, alat batu seperti beliung dan belincung ruparupanya masih digunakan sebagai peralatan sehari-hari baik sebagai perkakas rumah tangga maupun alat pertanian oleh masyarakat yang tinggal di kawasan danau.

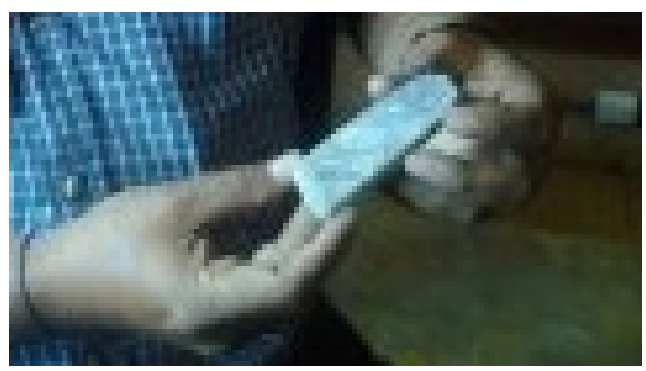

Gambar 10. Temuan ipon-pungi, Beliung dari Takengon, Gayo, Provinsi Aceh.

(Sumber: lintasgayo.co 2013.)

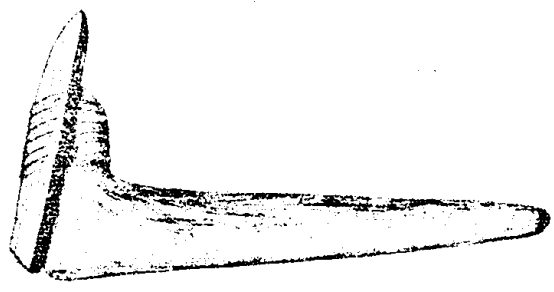

Gambar 11. Neolithic hoe (Sumber: Oakley 1972, 88)

Beliung dan belincung pada umumnya disebut juga dengan istilah Neolithic hoe yaitu kapak batu yang telah diupam dan dalam penggunaannya diikatkan pada kayu sehingga bentuknya menyerupai cangkul (Oakley 1972, 88; lihat gambar). Lebih lanjut dijelaskan oleh Kenneth $P$. Oakley bahwa beliung dan belincung banyak ditemukan di lokasi permukiman awal pertanian, yang biasanya permukiman tersebut terletak di dekat mata air, sungai ataupun danau, dan masyarakatnya memiliki kebiasaan bercocok tanam dan berburu (Oakley 1972, 88-90).

Van Heekeren dalam buku The Stone Age of Indonesia menyebut Beliung dengan Rectangular Adze dan Belincung dengan istilah Pick Adze (Heekeren 1972, 160-161). Menurut R. $P$. Soejono di Indonesia, beliung merupakan alat batu yang paling dominan pada masa bercocok tanam. Daerah penemuannya hampir meliputi seluruh kepulauan di Indonesia, terutama di Indonesia Bagian Barat. Di luar Indonesia, beliung juga ditemukan di wilayah yang dihuni oleh masyarakat penutur rumpun bahasa Austronesia seperti Malaysia, Thailand, Vietnam, Kamboja, Jepang, Taiwan, Filipina, dan Polinesia. Beliung dengan ukuran lebih besar dan lebih tebal, sehingga memiliki penampang lintang segitiga atau setengah lingkaran disebut dengan istilah belincung dan berfungsi sebagai alat untuk memotong kayu ataupun untuk mencangkul tanah dan bercocok tanam (Soejono 1992, 171-180). Berdasarkan bentuk atau tipologinya, Soejono membedakan Beliung menjadi 5 (lima) macam yaitu : Beliung Bahu Sederhana, Beliung Tangga, Beliung Atap, Beliung Biola, dan Beliung Penarah, sedangkan beliung yang ditemukan di kawasan danau-danau di Jawa Timur tidak ada yang dapat dimasukkan dalam tipe-tipe tersebut. Beliung-beliung yang ditemukan dari hasil penelitian di kawasan danaudanau di Jawa Timur dapat dikelompokkan menjadi dua tipe seperti yang dilakukan oleh Heekeren (1972), yaitu tipe rectangular adze dan pick adze. 


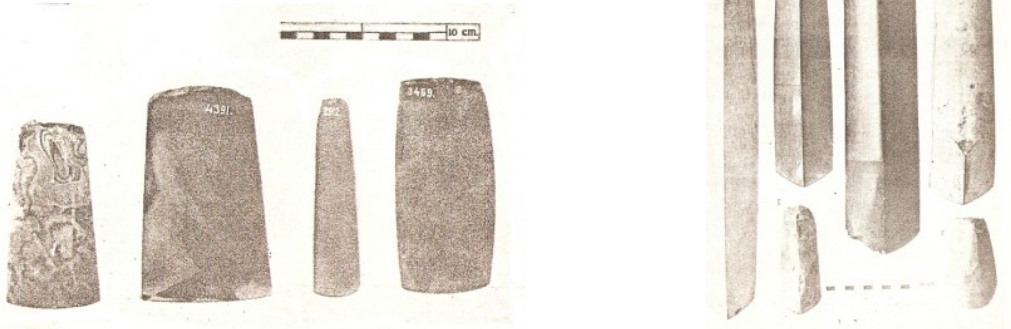

Gambar 12. Rectangular Adze (kiri) dan Pick Adze (kanan) (Sumber: van Heekeren 1972, PL 81 dan PL 82).

Salah satu cara untuk mengetahui dari mana asal-muasal beliung yang ditemukan di kawasan danau-danau di Jawa Timur yaitu dengan melakukan analisis petrografi baik dari sampel beliung maupun sampel batuan setempat. Selain itu, juga perlu dilakukan analisis petrografis untuk sampel dari situs lain yang telah diketahui sebagai situs perbengkelan beliung seperti Situs Punung, Pacitan, Situs Kendeng Lembu, Kabupaten
Banyuwangi di sebelah Timur dan Situs Tipar-Ponjen, Kabupaten Purbalingga, Jawa Tengah yang letaknya cukup jauh dari danau-danau di Jawa Timur. Permasalahannya dari Situs Kendeng Lembu sampai ditulisnya artikel ini belum dapat diperoleh sampel yang diharapkan. Hasil analisis petrografis dari beberapa sampel beliung dan sampel data pembanding yang ditemukan di kawasan danau-danau di Jawa Timur menunjukkan bahwa :

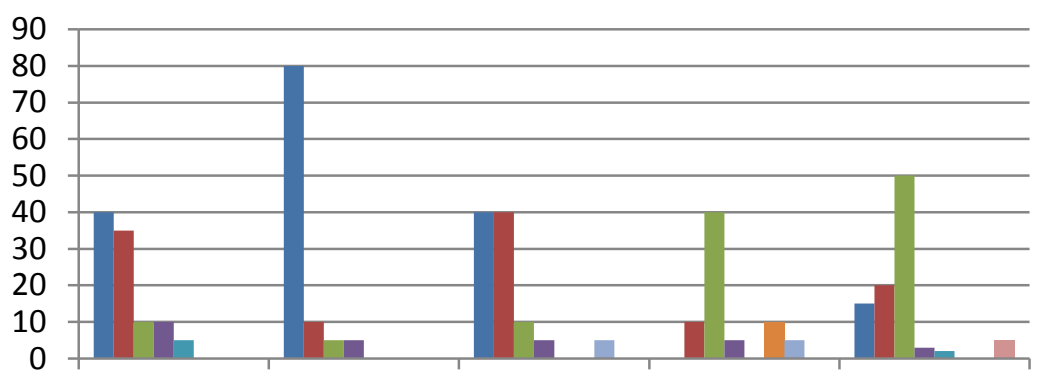

Beliung Ranu Beliung Ranu Beliung Ranu Beliung Ranu Batuan Lokal Bethok-1 Bethok-2 Segaran-1

Segaran-2 Kawasan
Ranu Bethok

\section{Gelas \\ Mineral Opak \\ - Plagioklas \\ - Quartz \\ Hornblende \\ Mud}

Lithic

Sanidin

Gambar 13. Hasil analisis petrografis terhadap sampel beliung

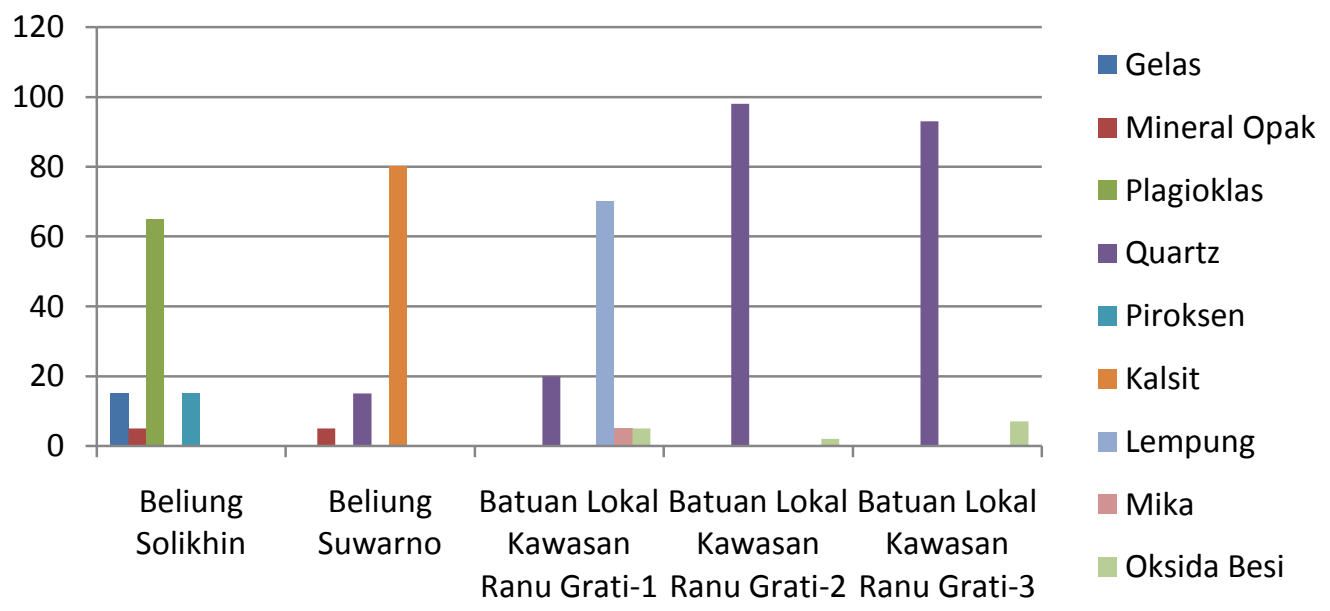

Gambar 14. Hasil analisis petrografis terhadap sampel pembanding 
Beliung-beliung yang ditemukan di kawasan danau-danau di Jawa Timur diperkirakan didatangkan dari tempat 栾@ lain, hal ini karena tidak didukung oleh sumber bahan baku yang ditemukan di kawasan tersebut. Akan tetapi daerah lain yang dimaksud belum dapat dibuktikan mengingat terbatasnya sampel data untuk analisis petrografis. Namun demikian, secara makrokospis (mata telanjang) bahan beliung dan belincung Ranu yang sebagian besar dibuat dari batuan rijang hijau dan silicified sandstone, memiliki kesamaan dengan beliung dan belincung dari Situs Kendenglembu. Dengan demikian, dapat disimpulkan sementara bahwa Beliung dan Belincung yang dtemukan di kawasan danau-danau di Jawa Timur kemungkinan besar berasal dari Situs Kendenglembu.

\section{PENUTUP}

Walaupun penelitian tentang beliung di kawasan danau-danau di Jawa Timur belum dapat menjawab semua pertanyaan penelitian terkait dengan asal-muasal beliung tersebut, akan tetapi temuan beliung dan belincung di Kawasan danau-danau di Jawa Timur, setidak-tidaknya dapat melengkapi data sebaran temuan beliung Neolitik di Jawa khususnya dan di Indonesia pada umumnya. Sejak terbitnya buku The Stone Age of Indonesia tahun 1972 hingga sekarang rupanya belum ada data baru dari daerah Jawa Timur. Hasil penelitian ini dapat memberikan sumbangan informasi dan data baru tentang sebaran beliung di Jawa.

Tidak ada satupun beliung ataupun belincung yang ditemukan di kawasan danau-danau di Jawa Timur berasal dari ekskavasi atau hasil penelitian langsung. Benda-benda tersebut pada umumnya ditemukan oleh masyarakat di 142rgani, kebun, ataupun saat menggali pasir. Selain itu ada pula yang berasal dari orang tua atau merupakan benda warisan secara turuntemurun. Dengan demikian, ada dua jenis beliung dan belincung yang ditemukan di kawasan danau-danau di Jawa Timur, yaitu beliung dan belincung sebagai alat sehari-hari, dan yang kedua merupakan benda pusaka yang dikeramatkan.

Berdasarkan kesimpulan di atas diketahui bahwa berbagai pertanyaan penelitian perlu dikembangkan dan dilakukan kajian-kajian yang lebih mendalam. Seperti misalnya kajian fungsi beliung dan belincung berdasarkan analisis bekas pakai yang harus dilakukan dengan menggunakan Scanning Electron Microscope (SEM) di bagian tajaman kedua jenis alat batu, baik yang ditemukan di areal perladangan ataupun yang dijadikan sebagai benda regalia. Hasil analisis phytolit (sisa-sisa 142rganic) akan dapat mengungkapkan apakah beliung yang digunakan sebagai benda regalia saat ditemukan dalam penelitian merupakan beliung yang sama sekali tidak digunakan sebagai alat atau sebaliknya. Apabila ternyata beliung yang saat ini masih diyakini oleh masyarakat sebagai benda bertuah ternyata memiliki retus dan sisa-sisa material yang tertinggal di bagian tajaman tersebut, maka diketahui adanya gap atau keterputusan budaya antar generasi pengguna beliung tersebut. Oleh karena itu, penelitian dan kajian serta analisis lebih mendalam tentang temuan beliung dan belincung di kawasan danau-danau di Jawa Timur masih perlu dilakukan. 


\section{DAFTAR PUSTAKA}

Anonim. 1979. "Ekskavasi Situs Mujan II, Purbalingga, Jawa Tengah". Laporan Penelitian Arkeologi No. 5. Balai Arkeologi Yogyakarta.

Anonim. 1997. Buku Panduan Analisis Pusat Penelitian Arkeologi Nasional dan BalaiBalai Arkeologi. Jakarta: Pusat Penelitian Arkeologi Nasional.

Bellwood, Peter. 2000. Prasejarah Kepulauan Indo-Malaysia, Edisi Revisi. Jakarta: Penerbit PT. Gramedia Pustaka Utama,.

Childe, V. Gordon. 1965. Man Makes Himself, Fourth Edition. The Fontana Library.

Gunadi, dkk. 2008. "Permukiman Masa Lampau di Tepian Danau, Desa Ranu Gedang". Laporan Penelitan Arkeologi. Balai Arkeologi Yogyakarta.

2009. "Permukiman Masa Lampau di Tepian Danau, Desa Ranu Segaran". Laporan Penelitan Arkeologi. Balai Arkeologi Yogyakarta.

2010. "Permukiman Masa Lampau di Kawasan Ranu Bethok, Desa Ranu Gedang". Laporan Penelitan Arkeologi. Balai Arkeologi Yogyakarta.

2011. "Permukiman Masa Lampau di Kawasan Ranu Bethok Tahap II, Desa Ranu Agung". Laporan Penelitan Arkeologi. Balai Arkeologi Yogyakarta.

2012. "Permukiman Masa Lampau di Kawasan Danau Grati, Kecamatan Grati, Kabupaten Pasuruan". Laporan Penelitan Arkeologi. Balai Arkeologi Yogyakarta.

2013. "Permukiman Masa Lampau di Kawasan Danau Ranu Grati, Desa Gratitunon”. Laporan Penelitan Arkeologi. Balai Arkeologi Yogyakarta.

Heekeren, H.R. Van. 1972. The Stone Age of Indonesia, Second Revised Edition. The Haguae - Martinus Nijhoff.

Koentjaraningrat. 1982. Manusia dan Kebudayaan di Indonesia. Jakarta: Penerbit Djambatan.

Masinambow, E.K.M., dkk. 2004. "Polemik Tentang Masyarakat Austronesia, Fakta atau Fiksi?" dalam Prosiding Kongres IImu Pengetahuan VIII. Kerjasama Lembaga IImu Pengetahuan Indonesia dan Direktorat Jenderal Pendidikan Tinggi, Departemen Pendidikan Nasional.

Menotti, Francesco. 2004. Living on the Lake in Prehistoric Europe, 150 years of lakedwelling research. Routledge. New York: Taylor \& Francis Group.

Nitihaminoto, Goenadi, dkk. 2007-2008. "Pola Permukiman Masa Lampau di Kawasan Ranu Klakah”. Laporan Penelitian Arkeologi. Balai Arkeologi Yogyakarta.

Noerwidi, Sofwan. 2008. Archaeological Research of Kendenglembu Site, East Java. Artikel untuk Anthony F. Granucci Fund and Indo Pacific Prehistory Association. Tidak terbit.

Oakley, Kenneth P. 1972. Man The Tool Maker, Sixth Edition. Chicago University Press. 
Renfrew, Colin dan Bahn, Paul. 2014. The Cambridge World Prehistory: Africa, South and Southeast Asia and the Pacific. Cambridge University Press.

栾@ Siregar, Darwin A. 2014. The Result of Radiocarbon Dating Measurement. Radiocarbon Dating Laboratory, Geological Survey Centre. Tanggal penghitungan : 5 - 11 2014.

Soejono R.P. dan Leirissa (ed.). 1992. Sejarah Nasional Indonesia I, Edisi Pemutakhiran. Jakarta: PT. Penerbit dan Percetakan Balai Pustaka.

Stein Callenfels, P.V. van. 1929. "Pre-historic remains in Poenoeng, Sampoeng and Dander (excursion E)" dalam Fourth Pacific Science Congress 4. Jakarta/Bandung. HIm.1-7.

www.lintasgayo.co/2013/06/21warga-takengon-temukan-ipon-pungi 